\title{
$\mathrm{Ni}$ の液相拡散接合における等温凝固挙動
}

\author{
才田一幸* 周 運鴻**† Thomas H. North** \\ *大阪大学工学部生産加工工学科 \\ **トロント大学治金・材料科学工学科 \\ J. Japan Inst. Metals, Vol. 58, No. 7 (1994), pp. 810-818

\section{Factors Affecting Isothermal Solidification during Transient Liquid Phase-Brazing of Nickel} \\ Kazuyoshi Saida*, Yunhong Zhou** and Thomas H. North** \\ *Research Associate, Department of Welding and Production Engineering, Faculty of Engineering, \\ Osaka University, Suita \\ **Department of Metallurgy and Materials Science, University of Toronto, Ontario, Canada
}

The effects of base metal grain size and quenching method form the brazing temperature on isothermal solidification during TLP-brazing with Ni-11 mass $\% \mathrm{P}$ filler metal were investigated. Single crystal, coarse-grained and fine-grained nickel base metals were brazed at $1423 \mathrm{~K}$ for various holding times, and the test specimens were then air-cooled, oil-quenched or water-quenched. Scanning electron microscopy and element analysis revealed that the eutectic width produced in air-cooled and in oil-quenched samples were smaller than that in the water-quenched specimens. This difference in eutectic width was due to different solidification modes occurring during cooling from the brazing temperature.

The eutectic width decreased linearly with the square-root of the brazing time in single crystal, coarse-grained and fine-grained nickel base metals. The completion time for isothermal solidification decreased in the order of single crystal, coarse-grained and fine-grained base metals. The difference in isothermal solidification rates produced when brazing the different base metals could be explained qualitatively by the influence of base metal grain boundaries on the apparent mean diffusion coefficient of phosphorus in solid nickel.

(Received March 8, 1994)

Keywords: transient liquid phase brazing, nickel, single crystal, nickel-phosphorus filler metal, isothermal solidification, microstructure, solidification mode, grain boundary, diffusion

\section{I. 緒言}

液相桩散接合(TLP 接合) は，低融点インサート枋を接合界 面に挿入して，加熱・溶融・保持し，接合部に形成された融液 内の融点降下元素を母材に拡散させることにより，等温凝固を 生じさせて接合する方法である。この夜相拡散接合過程は，3 つの連続する過程, すなわち，母材溶融過程，等温凝固過程お よび均一化過程からなっている.このうち，等温凝固過程につ いては, 等温㠜固自体が液相拡散接合現象の中で最も重要から 特徵的な現象で西ることから，これまで比較的多くの調查・検 討がなされてきた，※た，母材溶融過程についてる，溶融金属 による固体金属の溶解反応ならびにらう付現象のひとつとして ある程度の検討が行われてきた。一方，均一化過程は接合体中 の構成元素の固相拡散現象が主なプロセスであり, 現象論的に はあまり興味深い検討は報告されていない。

これすでの研究事例をまとめると，液相拡散接合現象の詳細 な解明(1)-(5)和さび単純なモデル化に基づく接合過程の解
析(1)-(3)(6)-(8)などが行われている、筆者らは，これまで一次元 有限差分沠による母村溶融衿よび等温凝固過程の連続モデル化 を行い,インサート材厚和よびインサート材融点から接合温度 までの加熱速度が母材溶融過程の重要な影響因子であることを 示すとともに(9)，液相拡散接合の連続した各過程を相境界移動 モデルルより，分断することなくひと続きに解析する手法につ

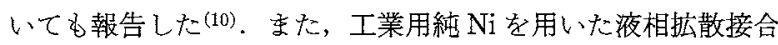
実験では，等温凝固完了時間の予測值と実測值を比較した結 果, これらの值の差は固液界面の移動に及ぼす母材結晶粒径の 影響によるものであることが示唆された ${ }^{(11)}$.一方，母材溶融 扣よび等温凝固過程において，接合部では母材結晶粒界領域に 执いて溶融ろら材による清が形成され(液相浸入)，電子顕微鏡 観察㧍よびェレクトロン・チャンネリング・パターン (ECP) 解析によると浸入深さは結晶粒界構造に大さく依存しているこ とを報告した(12)。さらに，拡散と界面エネルギーの釣り合い の両方を考慮した二次元有限詩分法による液相拡散接合過程に 括ける固液界面の移動についてモデル化を試み，液相浸入現象 の解析す行ってきた ${ }^{(13)}$.このよらな一連の検討結果は, Tuah-Poku ら ${ }^{(14)}$ に上る液相浸入による等温凝固現象の差異に対 
して重要な示唆を与充るなど,これまでの研究結果をより系統 的に理解・説明できるすのとなっている.

このように，液相拡散接合現象は比較的広範园に険討がなさ れているが，母材溶融量・速度，等温凝固速度扣上び合金元素 の均質化達成時間などの液相拡散接合現象に及注す母材結晶粒 界の影響については，実験的には汪とんど明らかにされていな い. 特に，母材結晶粒界は固液界面の形状や移動現象に大きな 影響を及ぼしていることが示唆されているにるかかわらず，結 晶粒界の存在割合（すなわら結晶粒径）を変化させたときの液相 抁散接合現象の差異については，伍とんど検討がなされていな い，そこで本研究では，液相拡散接合過程のらら，主に等温凝 固過程に和ける固液界面の移動に及ぼす母材結晶粒界の影響に ついて検討することにした。

\section{II. 供試材料および実験方法}

\section{1. 供試材料}

接合には 3 種類の結晶粒径の異なる純 $\mathrm{Ni}$, すなわら, 単結 晶材，粗粒材および細粒材を用いた。これらの材料の純度なら びに形状をTable 1 亿示す，単結晶材は長手方向が[100]方向 であり，接合面を長手方向に垂直な $(100)$ 面とした，粗粒材は 一方向凝固材 (Ohno-cast 材 $\left.{ }^{(15)-(17)}\right)$ であり，真空中にて $1423 \mathrm{~K}$ $86.4 \mathrm{ks}$ の焼き鈍し熱処理後供試した。な特，鋯方向に垂直 な面での平均結晶粒径は約 $3.5 \mathrm{~mm}$ であり，接合面を鋳造方向

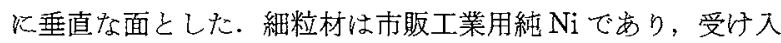
れのま供試した。受け入れ時の平均結晶粒径は約 $0.2 \mathrm{~mm}$ で ある。これらの材料を直径 $12 \mathrm{~mm}$, 厚さ $3 \mathrm{~mm}$ ない $5 \mathrm{~mm}$ に加工し接合に使用した，また，液相インサート材(ろら材)と

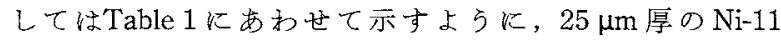
mass \%Pアモルファス簿学直径 $10 \mathrm{~mm}$ に加工して用いた。

\section{2. 実験方法}

(1) 接合方法

接合に先立ち，接合試料は接合面をエメリ一䋊 研磨後, インサート村とともにアセトン中で超音波洗浄した。 接合にあたっては，Fig. 1に示すように接合試料の間にイン サート材を括入した後，接合層幅を一定に保つために，純 Ni クランプを用いて接合試料をスポット溶接にて固定した。この 後, 接合過程に括ける溶融インサート材の流出を防止するため に，接合体側面にストップオフを塗布した。な和，単結晶材の 接合では両接合材の結晶方位を合わせて配置した。

接合はFig. 2 に示すよらな綎型真空炉を用いて行った。こ
の接合装置は真空䨌囲気中にて試料を油浴に落下させることに より急冷できるような構成となっている．Fig. 1 亿示した接合 試料を油浴直上の位置にせットし, 真空排気した。この後, 所 定の温度に加熱された炉体中央部分末で接合試料をすばやく引 き上げて, 所定の時間保持した後, 落下. 油冷させた。 また, 空泠あるいは水冷させる場合には, 同様傎空中で所定の時間 接合させた後, 冷却直前に炉中を完全にアルゴン置換し, 油浴 を取り去り大気中むしくは氷水中に落下させて冷却した. 本研 究に拉ける接合条件を単結晶材, 粗粒材および細粒材ごとに

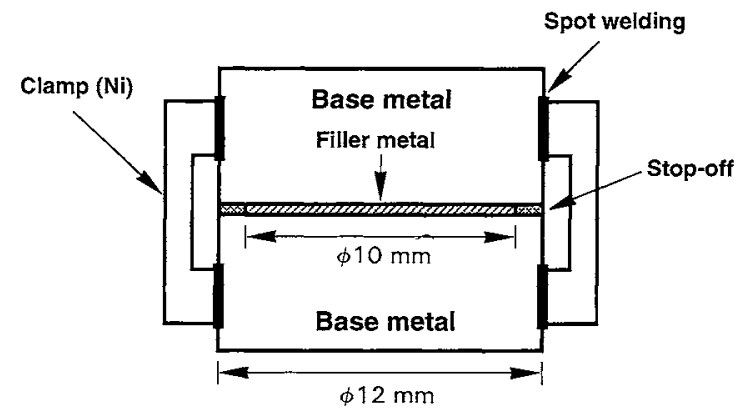

Fig. 1 Configuration of the TLP-brazing assembly.

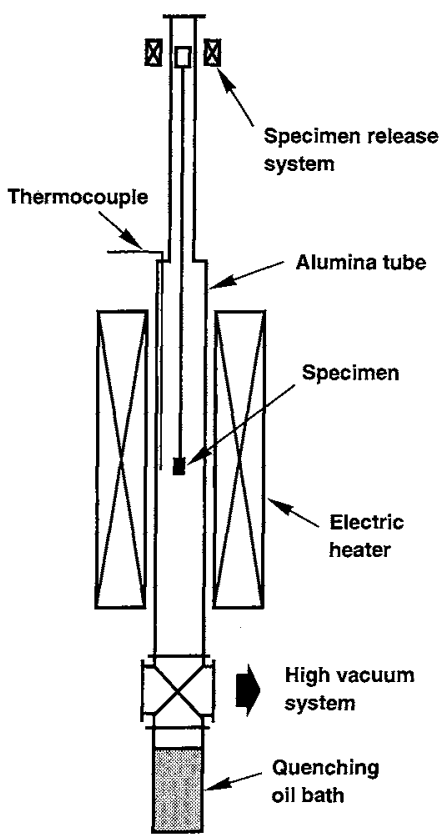

Fig. 2 Schematic illustration of the vacuum brazing furnace with the oil-quenching facility.

Table 1 Nickel base metals and filler metal used.

\begin{tabular}{|c|c|c|c|c|c|}
\hline \multicolumn{2}{|c|}{ Material } & $\begin{array}{c}\text { Purity } \\
\text { (mass\%) }\end{array}$ & $\begin{array}{c}\text { Grain size } \\
(\mathrm{mm})\end{array}$ & $\underset{(\mathrm{mm})}{\text { Dimension }}$ & Remark \\
\hline \multirow{3}{*}{$\mathrm{Ni}$} & Single crystal & 99.999 & $(12.5)$ & $12^{\phi} \times 3^{t}$ & (100) orientation, as-received \\
\hline & Coarse grain & 99.99 & 3.5 & $12^{\phi} \times 5^{t}$ & Ohno-cast Ni, $1423 \mathrm{~K} \times 86.4 \mathrm{ks}$ annealed \\
\hline & Fine grain & 99.5 & 0.20 & $12^{\phi} \times 5^{\mathfrak{t}}$ & As-received \\
\hline \multicolumn{2}{|c|}{ Filler metal } & \multicolumn{2}{|c|}{$\mathrm{Ni}-11$ mass $\% \mathrm{P}$} & $10^{\phi}$ & Thickness: $25 \mu \mathrm{m}$ \\
\hline
\end{tabular}

\footnotetext{
$\phi$ : Diameter, ${ }^{\mathrm{t}}$ : Thickness.
} 
Table 2 にまとめて示す．接合温度は $1423 \mathrm{~K}$ 一定とし，炉体 の温度は保持過程を通じて $\pm 5 \mathrm{~K}$ の範囲内に制御した．保持時 間は $60 \mathrm{~s} \sim 176.4 \mathrm{ks}$ の範团でそれぞれ変化させた。また，接 合試料の加熱速度を実測したところ，インサート材の融点と接 合温度の間で約 $10 \mathrm{~K} / \mathrm{s}$ であった．接合雾囲気はいずれも約 $10 \mathrm{mPa}$ の真空中であり, 冷却方法によりアルゴン置換も行っ た.

\section{（2）接合層の観察および共晶幅測定方法}

接合層の観察には光学顕微鏡ならびに走査型電子䫒微鏡 (SEM)を用い，接合部に拈ける定性および定量元素分析には エネルギー分散型 X 線分析装置 $(\mathrm{EDX})$ を使用した。接合層の 観察捛よび共晶幅の測定では，接合試料の観察面を濃硝酸十無 水酢酸(体積比 $1: 1$ ) 溶液にて腐食し, 組織を現出させた。 た，母材結晶粒径の測定では，同様に濃硝酸十濃塩酸十グリセ リン(体積比 $1: 2: 3$ ) 溶液にて結晶粒界を現出させた。共晶幅 は接合部断面の中央部 $5 \mathrm{~mm}$ 長さの接合層について評価した. 500 倍の観察倍率で共晶部分の断面積を測定し，接合層長さで 除した值を平均共晶幅とした。母材結晶粒径は接合界面全長に ついて測定し，接合層に接する母材結晶粒の平均粒径とした，

\section{III. 接合部組織に及ぼす冷却方法の影響}

等温凝固挙動を調查するにあたり，粗粒材を用いて接合部組 織に及ぼす冷却方法の影響について調查した。接合温度に括け る等温凝固中の固液界面の位置および動きを評価するパラメー タについて検討するとともに，以下の検討に拈いて採用する冷 却方法を選定した。

\section{1. 接合部組織および元素分析 \\ (1) 接合部組織}

冷却方法を変化させたとさの接合部組織を Fig. 3 に対比し て示す。これらの試料は接合温度 $1423 \mathrm{~K}$ ，保持時間 360 $480 \mathrm{~s}$ のほぼ同一接合条件範囲の接合部の光学顕微鏡組織であ る.な拈，この接合条件範囲は後述するように，等温凝固過程 のごく初期段階に相当している．いずれも中央部の暗い部分が 共晶に対応する領域であり，母材結晶粒界と考兄られる場所に おいて液相の浸入が認められる(12). 接合部組織は冷却方法に よりかなり異なっており，空冷および油冷試料では共晶領域と 母相の界面は比較的滑らかであるが，水冷試料では共晶領域中 に母相界面から突出した島状の相が多く認められ，非常に複雑 な界面形状となっている. また，水冷試料の共晶領域の幅は他 のものに比べ非常に広くなっていることがわかる.詳細な観察

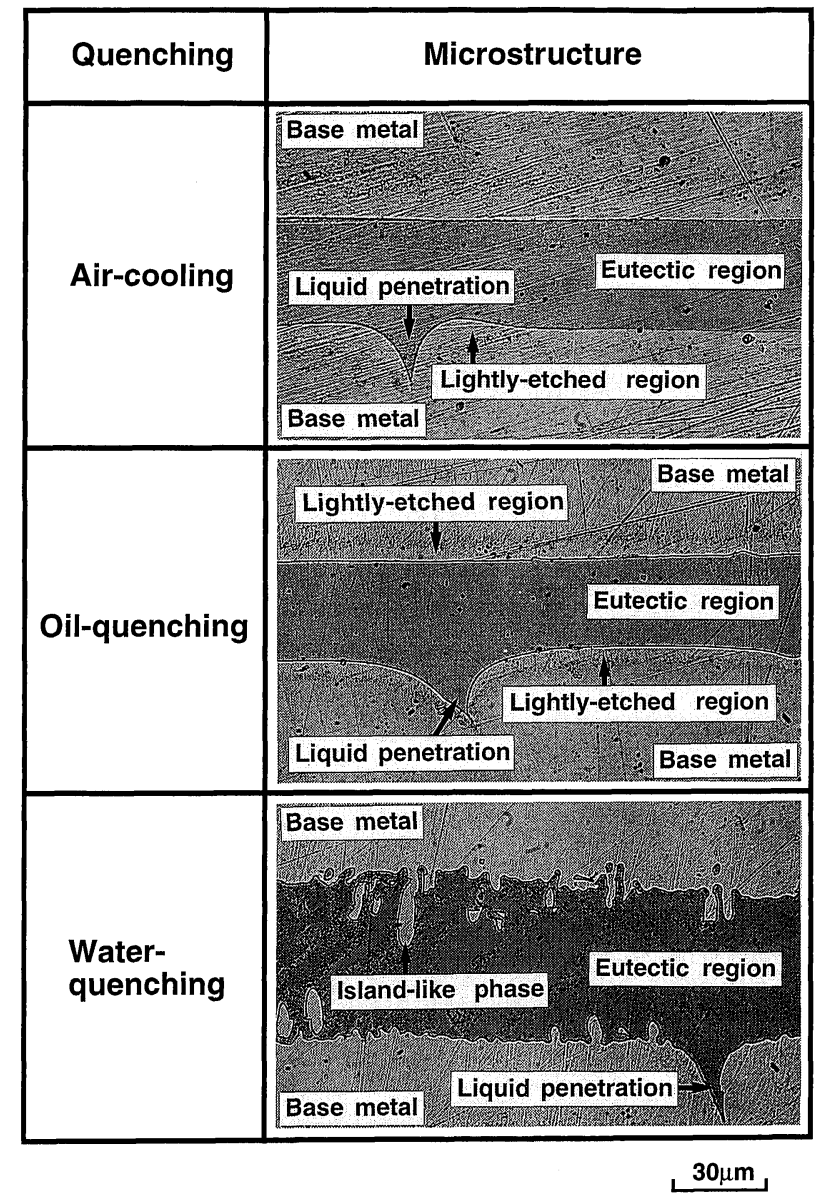

Fig. 3 Optical microstructures of brazed layer in different cooled test samples (following brazing at $1423 \mathrm{~K}$ for 360-480 s).

によると，空冷および油冷試料には，界面に接した母相中に母 材とは腐食の程度がやや異なる領域 (以下, 淡腐食領域と呼 ぶ.）が観察される。淡腐食領域と母材の境界は不明瞭である が，この境界間の距離，すなわち，共晶領域の幅と淡腐食領域 の幅の総和は, 水冷試料の共晶領域の幅にほぼ対応しているよ らである.一方, 光学顕微鏡観察によると水冷試料には淡腐食 領域は認められない。

な怙，これらの組織からはいずれも母材と等温凝固相の境 界, すなわら, 接合温度に拈ける母材溶解量ならびに最大液相 幅(母材溶融過程終了直後の固液界面の位置)を特定することは 不可能である.

Table 2 Brazing conditions applied to the different nickel samples.

\begin{tabular}{|c|c|c|c|c|c|}
\hline Base metal & Single crystal & \multicolumn{3}{|c|}{ Coarse grain } & Fine grain \\
\hline Brazing temp. & $1423 \mathrm{~K}$ & \multicolumn{3}{|c|}{$1423 \mathrm{~K}$} & $1423 \mathrm{~K}$ \\
\hline Brazing time & $480 \mathrm{~s} \sim 129.6 \mathrm{ks}$ & $60 \mathrm{~s} \sim 176.4 \mathrm{ks}$ & & & $60 \mathrm{~s} \sim 90 \mathrm{ks}$ \\
\hline Heating rate* & $10 \mathrm{~K} / \mathrm{s}$ & \multicolumn{3}{|c|}{$10 \mathrm{~K} / \mathrm{s}$} & $10 \mathrm{~K} / \mathrm{s}$ \\
\hline Quenching method & Oil-quenching & Oil-quenching & Air-cooling & Water-quenching & Oil-quenching \\
\hline Atmosphere & Vacuum & Vacuum & \multicolumn{2}{|c|}{ Vacuum-Argon } & Vacuum \\
\hline
\end{tabular}

Vacuum : $10 \mathrm{mPa},{ }^{*}$ : Measured value in specimens. 


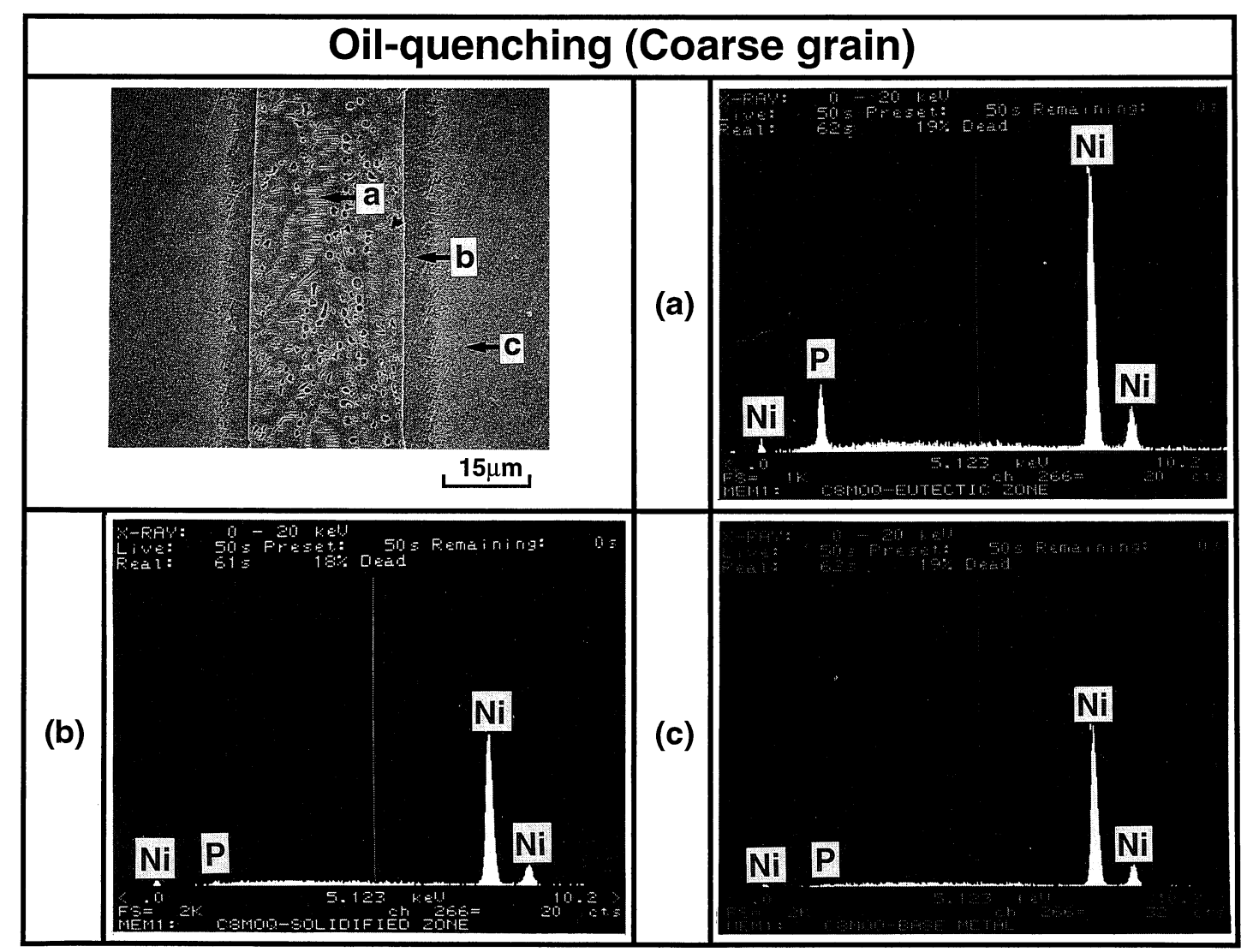

Fig. 4 Element analyses in the eutectic region and adjacent to the brazed layer in oil-quenched test specimen.

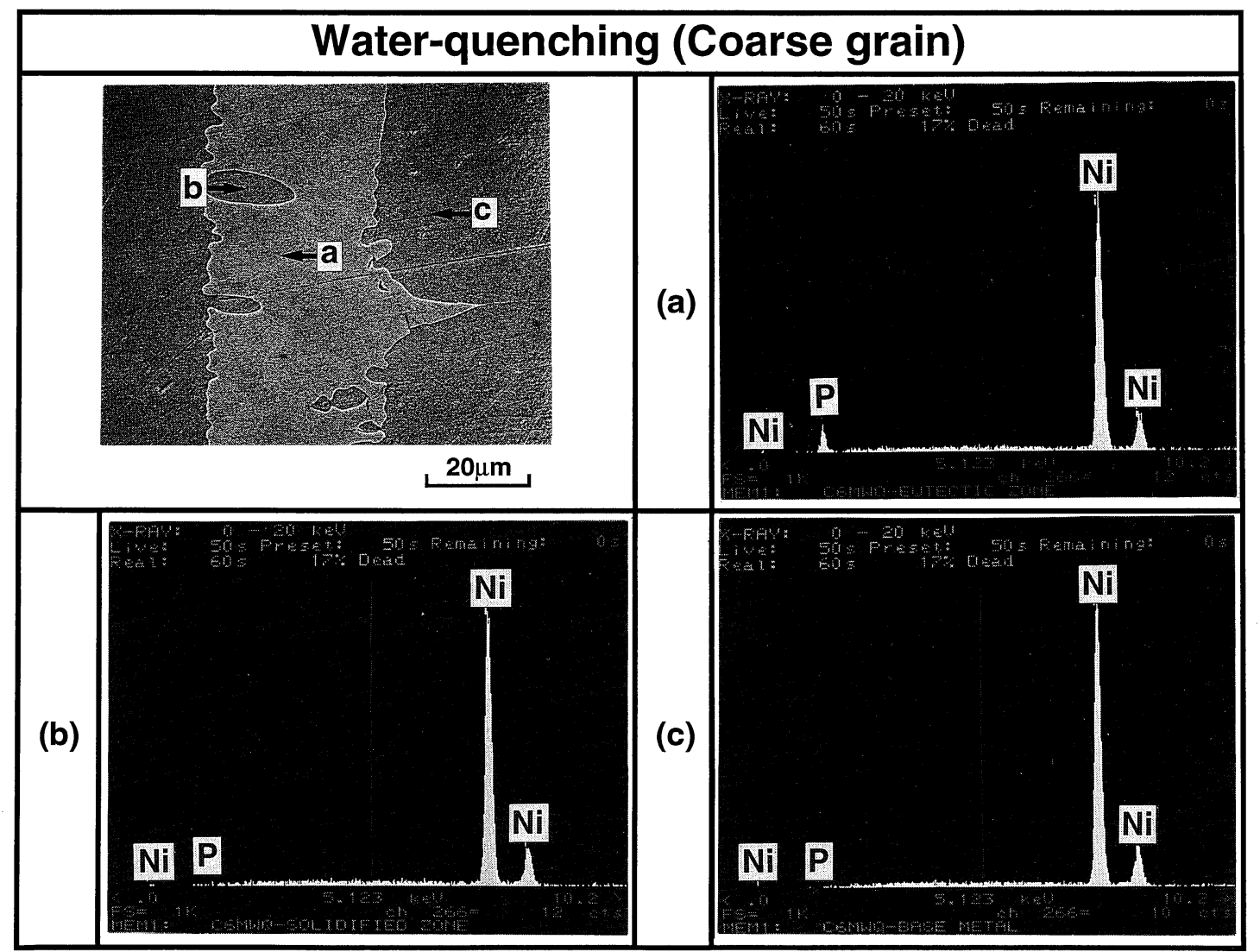

Fig. 5 Element analyses in the eutectic region and adjacent to the brazed layer in water-quenched test specimen. 


\section{(2) 接合部の元素分析}

油冷叔よび氷冷試料飞ついて EDXにより接合部における元 素分析を行った。油冷試料の接合部の EDX点分析結果を Fig. 4 に示す. 図中の SEM 組織によると，接合層中央部には 特徽的な共晶状組織が認められ，共晶領域に接して両母材側に 淡腐食領域も明確に観察される.SEM 組織中の 3 点 $\mathrm{a}$ ， bおよ びcはそれぞれ共晶領域，淡腐食領域および母材部分に対応 して特り，図(a)，(b)执よび(c)はそれぞれの部分の元素分析 結果を示している，共晶領域aでは，Niの他にPがかなり検 出されたが，淡腐食領域 $\mathrm{b}$ 和よび母材部分 $\mathrm{c} て ゙ は \mathrm{P} は$ はとん ぞ検出されず，Niのみが認められる．接合層に垂直力向に Ni 扣よびPの線分析を行ったが，Fig. 4の結果と全く同様な傾 向が得られ，Pは共晶部分心著しく濃化している他に，淡腐食 領域にごくわずかに分布していた。市た，Ni は接合部全域で 任と儿ど变化なく共晶領域に括いてわずかに減少していた。

Fig. 5 は办冷試料の接合部の EDX 点分析結果を同様に示し たものである.水冷試料では, SEM 組織からも淡腐食領域が 全く認められないことが確認された. SEM 組織中の 3 点 $\mathrm{a}, \mathrm{b}$ 扣よび c はそれぞれ共晶領域，島状相扣よび母材部分に対応 して括り，図(a)，(b)和上び(c)はそれぞれの部分の元素分析 結果を示している。この場合に执いてす，Pは共晶領域aのみ に括いて検出され，島状相 $\mathrm{b}$ 扣上び母材部分 $\mathrm{c}$ からはほとえ どNiのみが検出された。

\section{2. 䠊固モードに関する検討}

冷却方法による接合部組織の差異について，冷却時に和孔る 凝固モードの観点から検討することにした．Fig. 6(a) はNi-P 二元系状態図を模式的に示したものである(18)(19)、インサート 材の P 含有量は 19 at\% (11 mass\%)であり，接合温度 $1423 \mathrm{~K}$

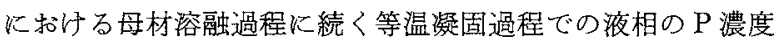
は C 点に位置している。C点から泠却するとき，冷却方法に

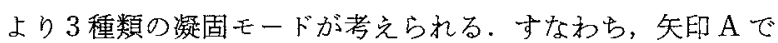
示される急冷凝固, 矢印 $\mathrm{E} て ゙$ 示される平衡凝固和よびこれら の中間的な凝固モード(矢印 B) である.Fig. 6(b)に示すよう そ，A 㧊よび B の凝固モードの場合の室温接合部組織は，そ れぞれ模式的に Type I 拉よび Type IIよらに図示すること ができるると考光られる。図中の $W_{e}$ は共晶幅, $W_{l}$ は接合 温度に和ける液相幅を示している. Type II 㠜固の場合, 共 晶幅 $W_{e}$ は Type Iのそれより大きく $W_{l}$ に近い値となり，共 晶部分の平均 $\mathrm{P}$ 組成は $\mathrm{B}$ 点で与光られるるのと推察される。 屯た, Ni 中のPの最大溶解度が非常飞小さいことから， Type Iの平滑に成長した固相およびType IIの母相界面から 島状に成長した相中のP P 濃度も非常に小さいものと考元られ る。

Fig. 7 は冷却方法を変化させたとさの接合層共晶中の平均 $\mathrm{P}$ 濃度の分析結果を示したもので务。. 図中のW.Q., O.Q. 括 よびA.C.はそれぞれ水冷, 油冷叔よび空冷を表して和り, 比 較としてインサート材のP 量の分析結果(F.M.) も亦わせて示

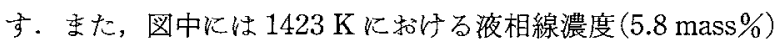
扣よび状態図上の共晶組成(11 mass\%) 位置も示している。い ずれの場合も共晶中の $\mathrm{P}$ 濃度は共晶点の濃度より小さくなっ ているが，水冷試料の共晶 $\mathrm{P}$ 濃度は空冷执よび油冷試料に比

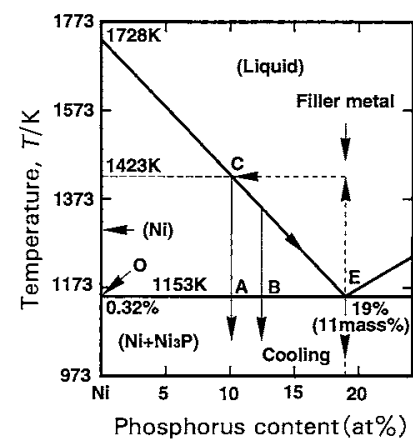

(a)
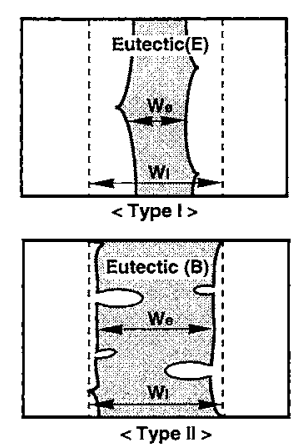

(b)
Fig. 6 Solidification mode during sample cooling.

(a) Phase diagram for the Ni-P system.

(b) Schematic illustrations of the solidification microstructures produced by different solidification modes.

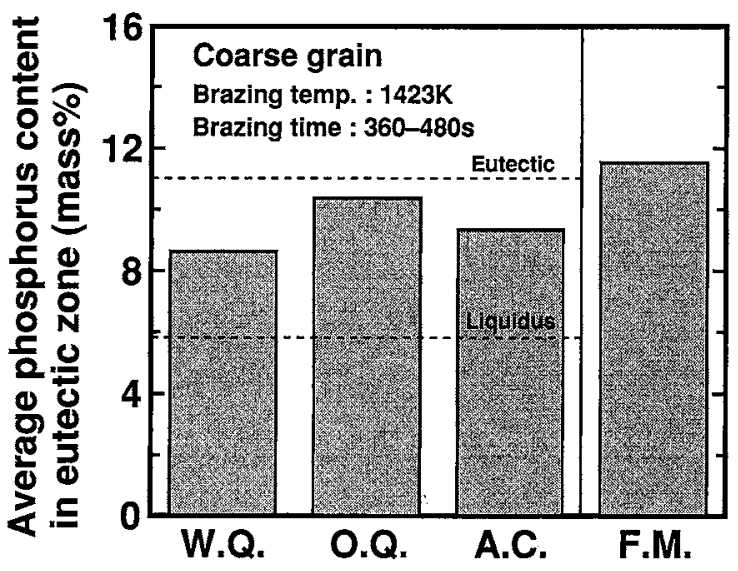

Fig. 7 Average phosphorus content in the eutectic region in air-cooled, oil-quenched and water-quenched test samples.

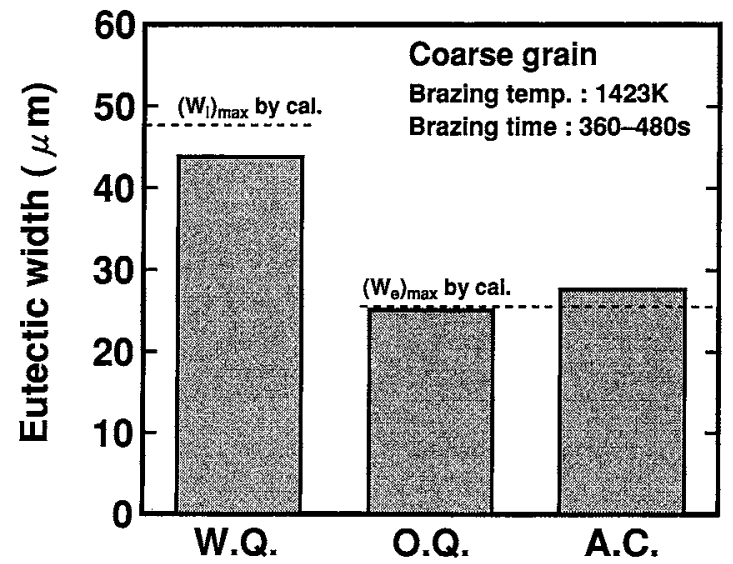

Fig. 8 Eutectic widths in test samples produced using different cooling conditions.

ベて，やや低くなっていることがわかる。

Fig. 8 は同样に冷却方法を変化させたときの共晶幅の変化 を比較して示したるのである. 水冷試料の共晶幅は空冷和よび 
油冷試料よりかなり大きくなっている. Fig. 6(a) に基づくと, 母材溶融過程終了直後の液相幅 $\left(W_{l}\right)_{\max }$ は, 近似的に以下の式 で概算することができる。

$$
\left(W_{l}\right)_{\max }=(O E / O A) t_{F}
$$

ここで, $t_{F}$ はろう材の厚さ $(25 \mu \mathrm{m})$ である. 一方, 接合温度か らの冷却中に平衡凝固が生じたとすると, 室温での共晶幅 $\left(W_{e}\right)_{\max }$ は以下のように表すことができる.

$$
\left(W_{e}\right)_{\max }=\left(W_{l}\right)_{\max }\left\{1+(A E / O A)\left(\rho_{e} / \rho_{s}\right)\right\}^{-1}
$$

ここで, $\rho_{e}$ は共晶の密度 $\left(7.97 \mathrm{~g} / \mathrm{cm}^{3(2)}\right), \rho_{s}$ は $\mathrm{Ni}$ 一次固溶体 の密度 $\left(8.91 \mathrm{~g} / \mathrm{cm}^{3(2)}\right)$ である. Fig. 8 中に式 $(1),(2)$ により 求めた $\left(W_{l}\right)_{\max }$ 招よび $\left(W_{e}\right)_{\max }$ の理論計算值を点線により示 す. 空冷括よび油冷試料の共晶幅は $\left(W_{e}\right)_{\max }$ の計算值 $(26 \mu \mathrm{m})$ とほぼ等しくなっているが, 水冷試料の共晶幅は $\left(W_{l}\right)_{\max }$ の計 算値 $(47 \mu \mathrm{m})$ よりわずかに小さい値となっていることがわか る.

これらのことを総合すると，Fig. 4 中の油泠組織中の淡腐食 領域 ( $\mathrm{b}$ 点) は, 接合温度からの冷却過程に扮いて母相界面より 平滑に凝固した $\mathrm{Ni}$ 一次固溶体であると推察され，母材と淡腐 食領域の境界は接合温度に和ける固液界面の位置を表している ものと考えられる.
また, 水冷試料では共晶幅が接合温度に拉ける液相幅よりわ ずかに小さい程度であり, 接合温度に梪ける固液界面の位置は ほ㳯そのまま共晶と母材境界の位置に対応しているものと予測 されるとともに, 島状の相は水冷過程で晶出した $\mathrm{Ni}$ 一次固溶 体であると考兄られる。したがって，空冷および油冷試料に拉 ける凝固モードはFig. 6 の Type I, すなわち, 平衡凝固に 非常に近い形態であり, 水冷試料の凝固モードは急冷凝固モー ドにかなり近いFig. 6 の Type IIのような急冷凝固と平衡凝 固の中間的な凝固形態となっていることが推察される.

このよらに，冷却方法により接合部の室温組織はかなり異な り，いずれも接合温度に括ける固液界面の位置あるいは液相幅 を厳密に特定することは困難である。しかしながら，接合温度 に括ける液相幅の評価パラメータとしては, 界面形状が非常に 複雑なため測定にかなりの手間を要する水冷による共晶幅をそ のまま用いる代わりに, 油冷あるい恃空冷による共晶幅から液 相幅を類推する方がより簡便で, ある程度の精度も保証できる と考えられることから, 以下の検討に执いては, 油冷試料によ る共晶幅を等温凝固挙動の評価パラメータとした.

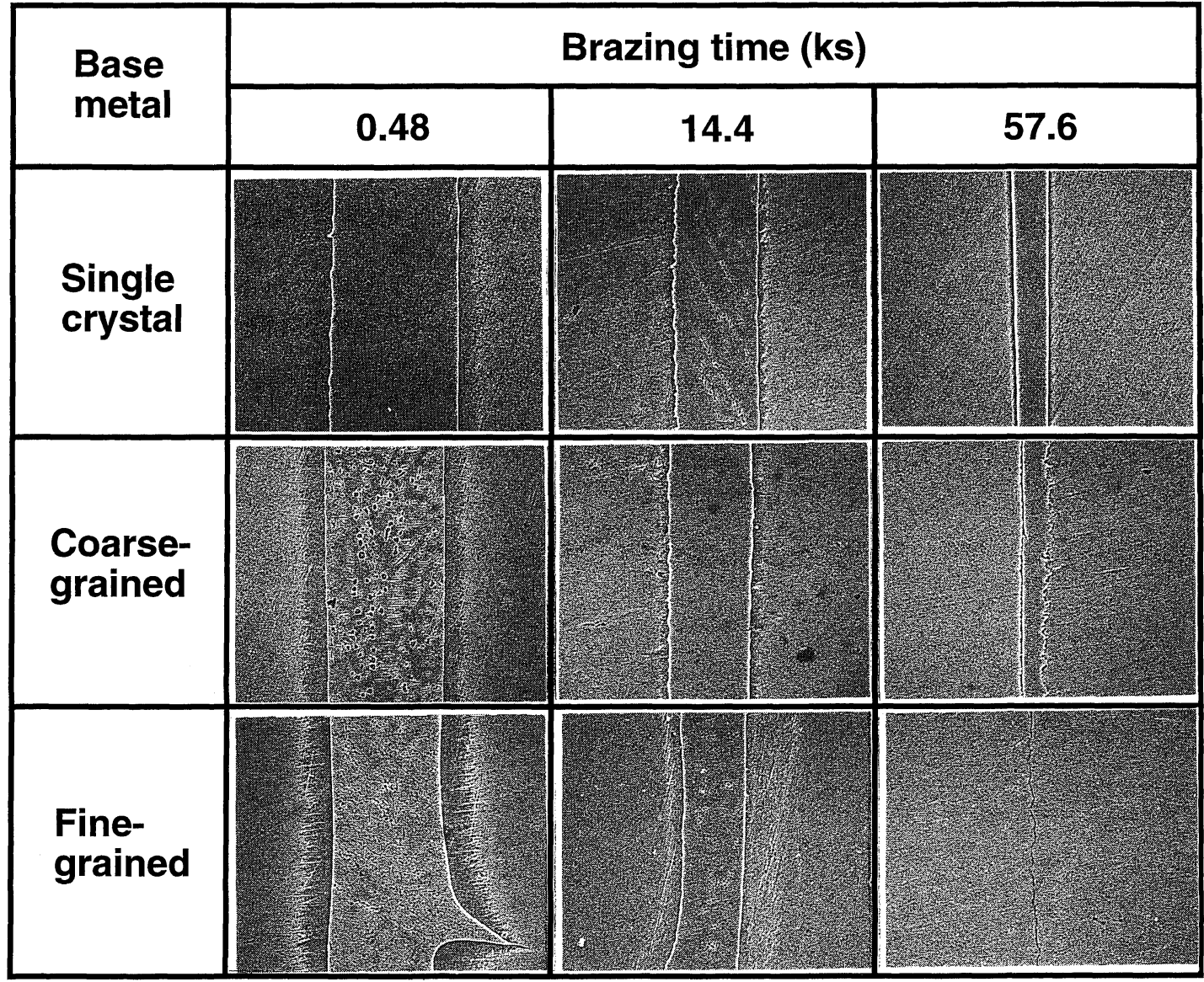

$20 \mu \mathrm{m}$

Fig. 9 Brazed layer microstructures produced at different holding times for nickel base metals having different grain sizes. 


\section{N． 等温疑固挙動に及ばす母材結晶粒径の影響}

\section{1. 等温疑固過程における共晶幅の変化}

TLP 接合過程における等温凝固挙動に及活す母材結晶粒径 の影響を調查するために, 単結晶材, 粗粒材および紐粒材 $\mathrm{Ni}$ を用いて接合温度 $1423 \mathrm{~K}$ で保持時間を変化させて接合した。

Fig. 9 は各母材ごとに保持時問を変化させたときの接合部組 織を比較して示したものである。保持時間はそれぞれ $480 \mathrm{~s}$ $\left(21.9 \mathrm{~s}^{1 / 2}\right), 14.4 \mathrm{ks}\left(120 \mathrm{~s}^{1 / 2}\right)$ 执よび $57.6 \mathrm{ks}\left(240 \mathrm{~s}^{1 / 2}\right)$ の 3 条件 であり，いずれも油冷組織である、いずれの保持時間に和いて も細粒材の共晶幅は単結晶材および粗粒材に比べかなり小さく なって招り長時間側の接合条件では, 共晶幅の美が非常に顕著 となっている，特に，保持時間 $57.6 \mathrm{ks}$ そおいては, 細粒材で は等温凝固が完了しているが，単結晶材および粗粒材では液相 が残存している.一方，いずれの接合試料に沶いてる，母材と 等温凝固相の間には明確な境界(粒界)は認められず，一様な組 織を呈していることから，等温凝固相が母村に対してエピタキ

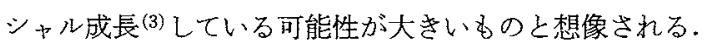

母材を変化させたときの共晶幅と保持時間の関係を Fig. 10 に示す. 共晶幅はいずれる保持時間の平方根に比例し减少して いる. 単結晶材拉よび粗粒材の共晶幅の消减速度は泳ぼ同じ程 度であるが，粗粒材の消滅速度はこれらに比べかなり速くなっ ている. 等温凝固過程のごく初期段階の共晶幅は, 母材溶解過 程終了直後の液相幅 $\left(W_{e}\right)_{\max }$ に注ぼ等しくなっているが，単結 晶材〉粗粒材〉細粒材の順にるずかながら減少している。

\section{2. 液相拡散接合過程における母材結晶粒成長}

等温凝固過程に乱ける粗粒材和よび細粒材の結晶粒成長現象 を予備的に調查した．Fig.11 は接合層近傍の結晶粒径に及ぼ す保持時間の影響を対比して示したすのである，粗粒材では初 期結晶粒径は $1423 \mathrm{~K}-86.4 \mathrm{ks}$ 焼きなむし状態のるのであるが， 若干のばらつきはるすのの結晶粒成長は忹とんど認められ ず，等温凝固過程を通した平均結晶粒径は $3.4 \mathrm{~mm}$ である. 一 万，細粒材では明確に結晶粒が成長して叔り，結晶粒径は

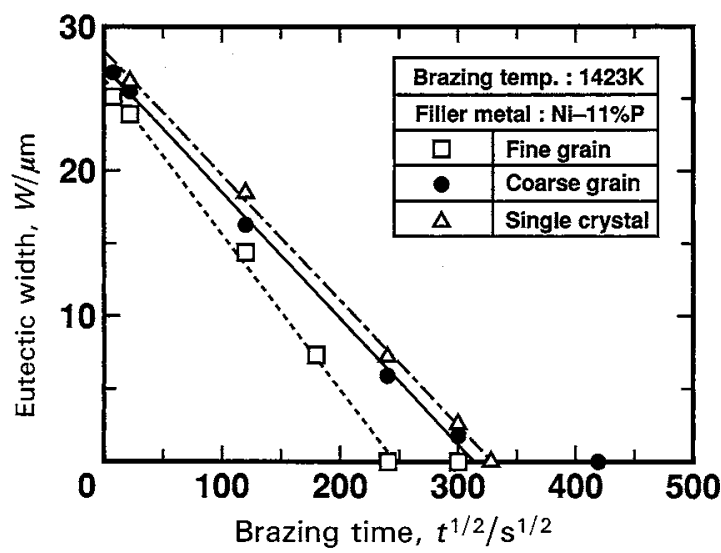

Fig. 10 Relation between the eutectic width and the square-root of the holding time for base metals with different grain sizes.
$200 \mu \mathrm{m}$ から $700 \mu \mathrm{m}$ なて増加している。な拈，細粒材の等温 凝固過程を通した平均結晶粒径は $480 \mu \mathrm{m}$ である。

\section{3. 等温疑固における母材結晶粒界の効果 \\ (1) 等温凝固速度および等温疑固完了時間}

母材結晶粒界の個数と等温凝固完了時間拉よび等温凝固速度 の関係を Fig. 12 火示す。母材結晶粒界の個数は接合層に接す る結晶粒の平均粒径の逆数と定義した。市た，等温凝固速度は Fig. 10 中の直線の傾きを示している.な抏，図中の実線は等 温凝固完了時間, 点線は等温凝固速度を表し, 横軸沈は平均結 晶粒径も㐫わせて示す，母材結晶粒界の個数の增加に伴い等温 凝固完了時間は注注直線的に減少し, 逆儿等温淡固速度は堌加 していることがわかる。

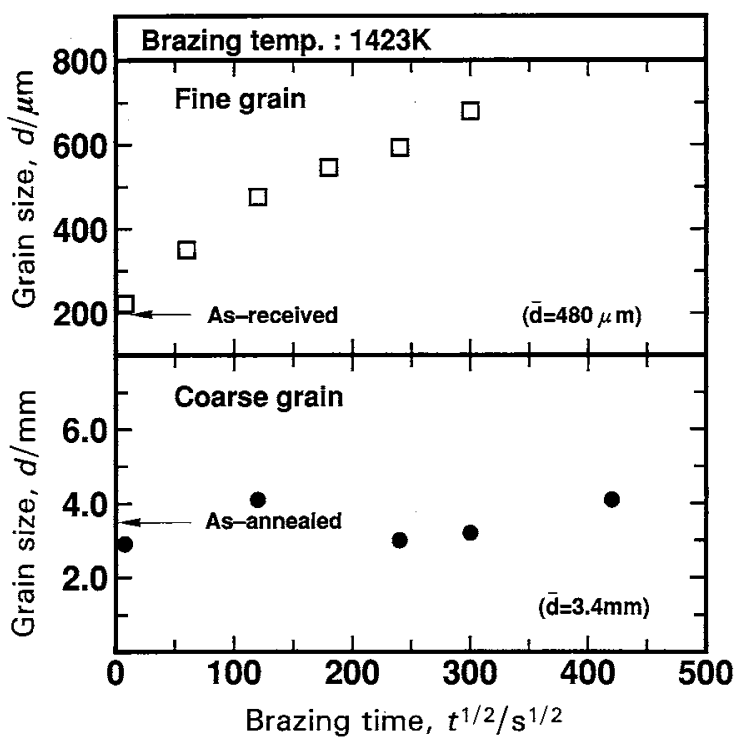

Fig. 11 Grain size/brazing time relation for fine- and coarse-grained nickel base metals.

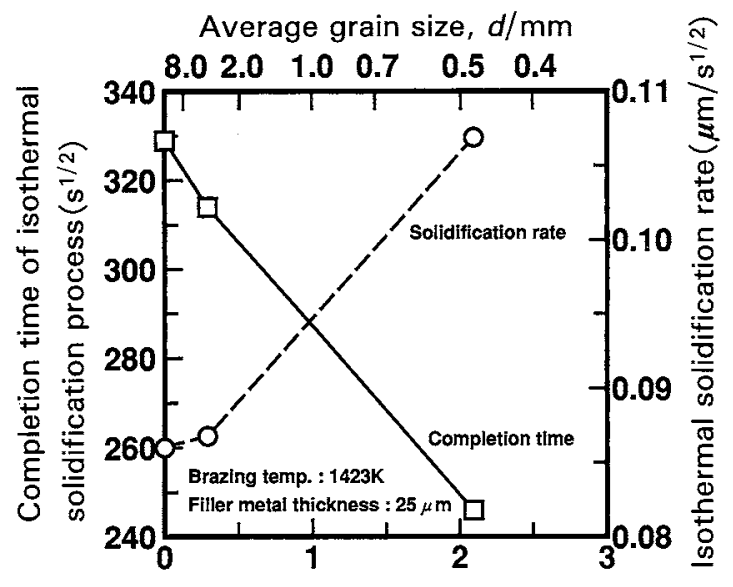

Grain boundary intercepts, $d / \mathrm{mm}^{-1}$

Fig. 12 Relation among the completion time for isothermal solidification, the rate of isothermal solidification and the base metal grain size (grain boundary intercepts value). 


\section{（2） 母材結晶粒界の効果に関する考察}

等温㠜固過程炕いては, 結晶粒界領域への液相の浸入(12) のみならず母材結晶粒の成長現象が認められ，等温凝固過程に 扣ける固液界面の移動を定量的に把握することは非常に困難で ある之考觉られる。そこで本研究では，等温㠜固に及注す母材 結晶粒界の影響を定性的に考察することにした。

これまでの報告(2)によると，等温凝周過程の接合温度飞拈け る時間 $t$ のきの液相幅 $W_{l}$ は以下の式で表すことができる.

$$
W_{l}=\left(W_{l}\right)_{\max }-\left\{4 C_{s} /\left(V_{s} \sqrt{\pi}\right)\right\}\left(C_{l} / V_{l}-C_{s} / V_{s}\right)^{-1} \sqrt{D_{P} t} \text { (3) }
$$

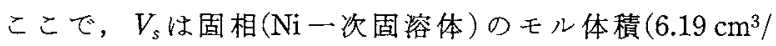
$\left.\mathrm{mol}^{(2)}\right), V_{l}$ は液相のモル体積 $\left(6.68 \mathrm{~cm}^{3} / \mathrm{mol}^{(2)}\right), D_{P}$ は固相 Ni 中の $\mathrm{P}$ の拡散定数, $C_{s}$ は固相線 $\mathrm{P}$ 濃度, $C_{l}$ は液相線 $\mathrm{P}$ 濃度で ある。な拉， $C_{s}$ 机上び $C_{l}$ (モル百分率 $)$ は, 状態図上り絶対温 度 $T$ の関数として,

$$
\begin{aligned}
& C_{s}=0.962-5.565 \times 10^{-4} T \\
& C_{l}=57.1-0.033 T
\end{aligned}
$$

で与兄られ(18)(19), 接合温度 $1423 \mathrm{~K}$ では， $C_{s}$ は 0.17 at\%, $C_{l}$ は 10.14 at\%である。

一方, 等温凝固過程に打ける共晶幅 $W_{e}$ と夜相幅 $W_{l}$ の関俰 は, 接合温度からの冷却過程において平衡凝固が生じるとす と, Fig. 6 から式 (2) と全く同様の

$$
W_{e}=W_{l}\left\{1+(A E / O A)\left(\rho_{e} / \rho_{s}\right)\right\}^{-1}
$$

で示される.これらのことから，Fig. 10 中の直線の傾き(等温 凝固速度) $m$ は,

$$
\begin{aligned}
m= & -\left\{1+(A E / O A)\left(\rho_{e} / \rho_{s}\right)\right\}\left\{4 C_{s} /\left(V_{s} \sqrt{\pi}\right)\right\} \\
& \times\left(C_{l} / V_{l}-C_{s} / V_{s}\right)^{-1} \sqrt{D_{P}}
\end{aligned}
$$

で表すことができる．したがって，Fig. 100 結果から，Ni中 のP の搪散定数を式 $(7)$ より逆算することができる. Fig. 13 は母材結晶粒界の個数と $\mathrm{Ni}$ 中の P の見かけの平均搪散定数の 関係を示したものである. 固相 $\mathrm{Ni}$ 中の $\mathrm{P}$ の搪散定数の測定例 は報告されていないため，図中には，中尾ら(2)によって同様な TLP 接合により求められた多結晶 $\mathrm{Ni}$ 中の $\mathrm{P}$ の抎散定数を対 比して示す．母材結晶粒界の個数が増加するのに伴い，見かけ の平均搪散定数が単結晶材く粗粒材く細粒材の順に大きくなっ

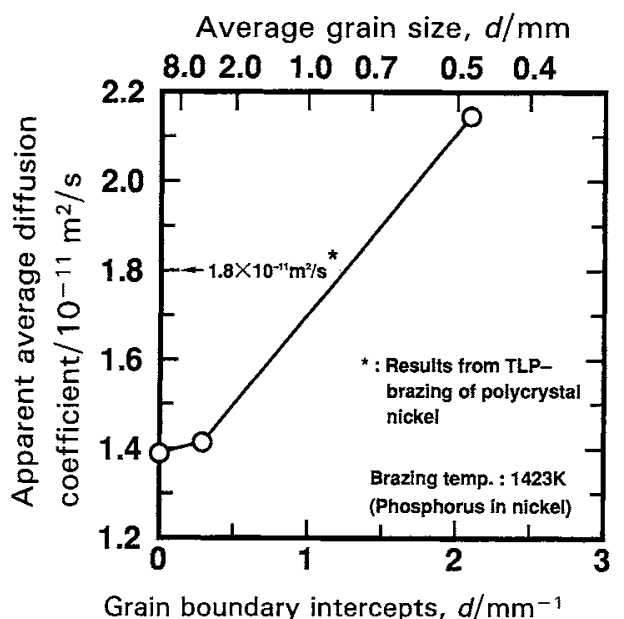

Fig. 13 Calculated apparent mean diffusion coefficient for phosphorus in solid nickel as a function of base metal grain size (grain boundary intercepts value).
ていることがわかる．また，中尾らの值は本研究の粗粒材と細 粒材の間に位置している，彼らの使用した Ni の結晶粒径は不

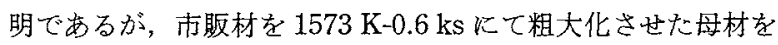
使用していることから，本研究に和いて使用した細粒村より結 晶粒径が大きいが，粗粒材よりは小さいるのと想像される。こ れらのことを考虑すると，本研究で得られた細粒材および粗粒 材の見か壮の平均拡散定数は，中尾らの結果之良く対応してい るものといえ, 逆算した拡散定数はいずれるほ济妥当な值を示 していると推察できる。

一般に，粒界拡散は体拡散に比べ非常に速いことが知られて

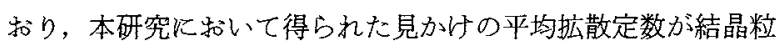
界の個数が多くなるに伴い大きくなることは，このことと定性 的に良く一致している．したがって，結晶粒界の存在に伴い単 結晶材<粗粒材<細粒材の順に見かけ平均拡散定数が大きく なることにより，等温㠜固速度(共晶消隇速度)が大きくなった ものと推察できる。な括，本考察結果によると，多結晶材の等 温凝固過程に颃いては母材結晶粒が成長することから, 厳密に は等温凝固速度 $m$ は時間の関数として变化することになる。 Fig. 11 括よび Fig. 13 に基つくと, 等温凝固の開始と完了時 点に打汁る $m$ の差は約 $20 \%$ 以内であり, 本実験では等温凝固 過程を通して住汸一定の等温凝固速度と見なされる結果が得ら れたるのと考えられる。

\section{V. 結 言}

本研究では，母材結晶粒径の異なる 3 種類の Niを Ni-11 mass\% $\mathrm{P}$ インサート材を用いて, TLP 接合 L，等温凝固過程 に和ける固液界面の移動に及ぼす母材結晶粒界の影響について 検討した．以下に得られた主要な結果を要約する。

(1) 接合温度からの泠却方法に上る接合部室温組織の差異を 調査したところ, 空冷括よび油冷試料の接合部に和ける共晶幅 は水冷試料に比べて狭くなっていた，この差は接合温度からの 冷却時の凝固モードの差によるるのと考光られ，空冷客よび油 冷でははぼ平衡凝固しているのに対して, 水冷試料では急冷凝 固に近い凝固形態になっているものと推察された。

(2) いずれの結晶粒径の母材を用いても，等温凝固過程にお ける共晶幅はいずれる保持時間の平方根に比例し減少した。 た，単結晶材和よび粗粒材の共晶幅の消娍速度はほぼ同じ程度 であるが，細粒材の消隇速度はこれらに比べかなり速くなって いた。

（3）母材結晶粒径化よる等温凝固速度の差は, 定性的には固 相 Ni 中の P の平均㧓散定数に及年す結晶粒界の影響に上るる のと説明できた。すなわち，結晶粒界の存在に伴い単結晶材 く粗粒材く細粒村の順に見かけの平均拡散定数が大きくなるこ とにより，等温凝固速度 (共晶消減速度)が大きくなったものと 推察できた。

本研究の一部は, Ontario Center for Materials Research (OCMR) おょよび Welding Research Council(New York)の財政 的援助を受けて実施し高した.ここに記して感謝の意を表しま す.また，本研究の遂行にあたり，実験面で御協力いただいた W. Fearis 氏(トロント大学)に厚く御礼申乙上げすす. 


\section{文献}

（1）中尾嘉邦, 西本和俊, 篠崎賢二, 姜 晶允, 堀 裕二: 溶接学会論文集, $6(1988), 519$

（2）中尾嘉邦, 西本和俊, 簙崎賢二, 姜 晶允: 溶接学会論 文集, 7(1989), 213.

（3）中尾嘉邦, 西本和俊, 篠崎賢二, 姜 晶允, 堀 裕二: 溶接学会論文集, $7(1989), 367$.

（4）中尾嘉邦, 西本和俊, 篠崎賢二, 姜 晶允, 重田春樹 : 溶接学会論文集, 9(1991)，55.

(5) W. F. Gale and E. R. Wallach: Metall. Trans., 22A (1991), 2451.

(6) S. Liu, D. L. Olson, G. P. Martin and G. R. Edwards: Welding J., 70(1991), $207 \mathrm{~s}$.

（7）并川 博, 中尾嘉邦, 以西俊範: 溶接学会誌, 47(1978), 440.

（8）恩沢忠男, 満氷 豊, 鈴村䀘男, 田村 博, 森川正樹 : 溶接学会誌，47(1978)，161.

(9) H. Nakagawa, C. H. Lee and T. H. North: Metall. Trans., 22A (1991), 543 .
(10) Y. Zhou and T. H. North: Modelling Simul. Mater. Sci. Eng., 1 (1993), 505.

(11) T. H. North, K. Ikeuchi, Y. Zhou and H. Kokawa: TMS Symposium, The Metal Science of Joining, 21st October (1991), in Cincinnati, Session 1, Paper 16

(12) H. Kokawa, C. H. Lee and T. H. North: Metall. Trans., 22A (1991), 1627.

(13) K. Ikeuchi, Y. Zhou, H. Kokawa and T. H. North: Metall. Trans., 23A(1992), 2905.

(14) I. Tuah-Poku, M. Dollar and T. B. Massalski: Metall. Trans., 19A (1988), 675.

（15）大野篤美：日本金属学会会報, 23 (1984), 773 .

(16) A. Ohno: Proc. Metallurgical Processes for the Year 2000 and Beyond, TMS, Las Vegas, NV, (1989), 155.

(17) A. Ohno, H. Soda, A. McLean and H. Yamazaki: Proc. Special Technical Programming Focus on Advanced Materials, SME, Salt Lake City, UT, (1990), 161.

(18) T. B. Massalski: Binary Alloy Phase Diagrams, Vol. 2, ASM International, Materials Park, OH, (1986).

(19) P. Nasn: Phase Diagrams of Binary Nickel Alloys, ASM International, Materials Park, OH, (1991). 